ISSN 2089-8673

Jurnal Nasional Pendidikan Teknik Informatika (JANAPATI)

Volume 2, Nomor 1, Maret 2013

\title{
PENGEMBANGAN SISTEM IDENTIFIKASI \\ JENIS KELAMIN JANIN PADA CITRA USG
}

\section{Oleh}

\section{Made Dendi Maysanjaya}

\section{Pembimbing}

1. Made Windu Antara Kesiman, S.T., M.Sc.

2. Dessy Seri Wahyuni, S.Kom., M.Eng.

\author{
Jurusan Pendidikan Teknik Informatika \\ Fakultas Teknik dan Kejuruan \\ Universitas Pendidikan Ganesha \\ Email :imade.dendi@gmail.com
}

\begin{abstract}
ABSTRAK
Penelitian ini bertujuan untuk: (1) merancang sistem identifikasi jenis kelamin janin pada citra USG, (2) mengimplementasikan sistem identifikasi jenis kelamin janin pada citra USG. Dalam perancangan dan pengimplementasiannya, penelitian ini menggunakan 3 jenis metode atau proses yang terdapat di dalam pengolahan citra digital yaitu: segmentasi citra, ekstraksi fitur, dan pengelompokan data. Inputan serta keluaran dari aplikasi ini adalah citra inputan yang berekstensi bitmap (*.bmp) dan keluarannya berupa informasi mengenai jenis kelamin janin. Pengujian dilakukan pada seluruh sampel yang dijadikan basis pengetahuan. Pada proses pengujian ini diperlukan bantuan dokter terlebih dahulu untuk mengidentifikasi jenis kelamin janin. Dalam merancang dan mengimplementasikan rancangan aplikasi, digunakan metode waterfall atau yang sering disebut dengan classic life cycle model.

Implementasi dan pengujian pada penelitian ini adalah suatu Sistem Identifikasi Jenis Kelamin Janin pada Citra USG yang menggunakan bahasa pemrograman Delphi. Dari data hasil uji performansi sistem didapat bahwa sistem mampu mengidentifikasi jenis kelamin janin hingga $66,67 \%$ dengan total sampel uji 54 citra USG. Berdasarkan hasil tersebut, Sistem Identifikasi Jenis Kelamin Janin pada Citra USG cukup membantu dokter kandungan dalam mengidentifikasi jenis kelamin janin.
\end{abstract}

Kata Kunci: Citra USG, Segmentasi, Ekstraksi Fitur, Pengelompokan Data 
ISSN 2089-8673

Jurnal Nasional Pendidikan Teknik Informatika (JANAPATI)

Volume 2, Nomor 1, Maret 2013

\title{
DEVELOPMENT OF IDENTIFICATION SYSTEM OF FETUS GENDERS' AT USG IMAGE
}

\author{
By \\ I Made Dendi Maysanjaya \\ Supervisors \\ 1. Made Windu Antara Kesiman, S.T., M.Sc. \\ 2. Dessy Seri Wahyuni, S.Kom., M.Eng. \\ Department of Informatic Technique Education \\ Faculty of Technique and Vocational \\ University of Pendidikan Ganesha \\ Email :imade.dendi@gmail.com
}

\begin{abstract}
This study aimed at: (1) designing the identification system of fetus gendersôat USG image, and (2) implementing the identification system of fetus gendersôat USG image. In designing and implementing the system, it was used three types of operation methods at digital image processing, namely: segmentation, features extraction, and data clustering. Input of these applications were image with extent bitmap (*.bmp), and its output is an information about fetus gendersô The test has been done on the entire image sample which has become a knowledge based. In the process of testing, it was initially needed the helping of an obstetrician in identifying the fetus gendersô In designing and implementing the application design, it was used a waterfall method which is usually called as a classic life cycle model.

The implementation and testing in this study was an identification system of fetus gendersô at USG image that were using a Delphi program. Based on the data of the performance system test about the accuracy of the system when identified the fetus gendersô it was found that until $66.67 \%$ could be identified well from 54 USG image sample. In this case, the identification system of the fetus gendersôwas very helpful for obstetricians when they would be identifying the fetus gendersô
\end{abstract}

Key words: USG Image, Segmentation, Features Extraction, and Data Clustering.

\section{PENDAHULUAN}

Pengolahan Citra Digital merupakan salah satu cabang ilmu informatika yang mempelajari mengenai citra, cara pengolahannya, serta implementasinya dalam kehidupan sehari-hari. Salah satu implementasi pengolahan citra misalnya pada bidang kedokteran, contohnya untuk Ultra Sonography (USG) kandungan. Pada hasil USG, 
ISSN 2089-8673

Jurnal Nasional Pendidikan Teknik Informatika (JANAPATI)

Volume 2, Nomor 1, Maret 2013

masih berupa gambar dua dimensi (2D) dan rata-rata kualitas gambar hasil cetakan cenderung gelap dan janinnya kurang jelas terlihat, sehingga tidak jarang dokter kandungan keliru dalam mengidentifikasi jenis kelamin janin tersebut, dan kecenderungan menimbulkan permasalahan mengenai akurasi dokter dalam memutuskan jenis kelamin janin. Meskipun demikian, sampai saat ini belum ada suatu sistem yang dapat digunakan untuk membantu dokter ketika memutuskan jenis kelamin dari sebuah janin.

Berdasarkan hal tersebut muncul sebuah ide untuk mengembangkan sebuah perangkat lunak, yang nantinya bisa digunakan oleh dokter kandungan pada saat mengidentifikasi jenis kelamin janin. Selain diharapkan bisa membantu dokter untuk mengidentifikasi jenis kelamin janin, diharapkan pula nantinya perangkat lunak tersebut bisa mengarah kepada terbentuknya sebuah sistem cerdas/sistem pakar, yang mana hal ini dapat dilakukan dengan menambah basis pengetahuan yang dimiliki oleh perangkat lunak tersebut.

Perangkat lunak yang dikembangkan memanfaatkan teknik pengolahan citra digital terhadap bentuk yang terkandung di dalam sebuah citra. Bentuk merupakan salah satu mode di mana manusia memberikan persepsi mengenai pengenalan suatu objek dalam lingkungannya (Sujaya, 2011). Pola dapat dikatakan sebagai representasi dari suatu bentuk yang memiliki makna tertentu, akan tetapi suatu bentuk belum tentu memiliki pola. Teknik pengenalan pola merupakan salah satu komponen penting dari mesin atau sistem cerdas yang digunakan baik untuk mengolah data maupun dalam pengambilan keputusan (Putra, 2010). Salah satu metode yang bisa digunakan untuk menganalisa pola bentuk yang dimiliki suatu objek adalah momen invarian. Momen dapat menggambarkan suatu objek dalam hal area, posisi, orientasi, dan parameter terdefinisi lainnya. Berdasarkan hasil analisa tersebut akan diperoleh sebuah vektor yang merepresentasikan fitur-fitur yang dimiliki sebuah objek.

Sebuah citra sampel USG agar bisa diidentifikasi jenis kelaminnya, maka diperlukan suatu metode pengelompokan data atau dikenal dengan istilah data clustering. Clustering merupakan proses pengelompokan objek atau data tidak berlabel ke dalam suatu kelas atau cluster dengan objek yang memiliki kesamaan (similarity). 
ISSN 2089-8673

Jurnal Nasional Pendidikan Teknik Informatika (JANAPATI)

Volume 2, Nomor 1, Maret 2013

Setiap kelompok, disebut cluster, memuat objek-objek yang saling memiliki kemiripan satu sama lain dan memiliki perbedaan jika dibandingkan dengan objek-objek yang terdapat pada kelompok atau cluster lain. Dalam pembagian data ke dalam kelompok tidak perlu mencocokkan secara detail dengan masing-masing objek, melainkan cukup mencocokkan dengan karakteristik kelompok secara umum (Abbas, 2008).

Berdasarkan latar belakang masalah yang telah diuraikan di atas dapat diketahui pokok permasalahan yang dihadapi adalah bagaimana rancangan dan implementasi Sistem Identifikasi Jenis Kelamin Janin dengan menggunakan pengolahan citra digital. Adapun tujuan yang ingin dicapai dalam penelitian skripsi ini adalah merancang dan mengimplementasikan Sistem Identifikasi Jenis Kelamin Janin dengan menggunakan pengolahan citra digital. Batasan masalah dari pengembangan Sistem Identifikasi Jenis Kelamin Janin dengan menggunakan pengolahan citra digital ini yakni: 1) citra uji maupun citra knowledge system yang digunakan berformat bitmap (*.bmp); 2) sistem belum bisa mengidentifikasi jenis kelamin untuk janin kembar; 3) citra yang digunakan sebagai knowledge system merupakan citra USG janin yang jenis kelaminnya sudah diidentifikasi oleh dokter kandungan; 4) sistem ini sifatnya hanya sebagai support system bagi dokter kandungan saat mengidentifikasi jenis kelamin janin; 5) tidak ditentukannya akurasi hasil yang diberikan sistem pada saat proses identifikasi; dan 6) citra uji maupun citra knowledge system yang digunakan merupakan citra USG janin berusia 6 bulan hingga 9 bulan.

\section{METODOLOGI}

Dalam penelitian ini menggunakan 3 metode yang terdapat dalam pengolahan citra digital yakni sebagai berikut.

\subsection{Segmentasi Citra}

Segmentasi citra merupakan proses pengolahan citra yang bertujuan memisahkan bagian objek (foreground) dengan latar belakang (background) (Putra, 2010). Cara pertama kali yang wajib dilakukan adalah mengubah citra menjadi citra biner, dengan menggunakan fungsi pengambangan (thresholding). Hal ini dikarenakan pada citra biner intensitas warna akan terlihat secara jelas perbedaannya, yang diakibatkan nilai 
pixel hanya terdapat dua jenis warna yaitu hitam dan putih. Terdapat dua jenis pengambangan, yaitu pengambangan global (global thresholding) dan pengambangan secara lokal adaptif (locally adaptive thresholding) (Putra, 2010).

Pada pengambangan global, semua pixel pada citra dikonversikan menjadi hitam atau putih dengan satu nilai ambang $\mathrm{T}$. Oleh karena menggunakan satu nilai ambang $\mathrm{T}$ untuk semua nilai pixel, maka kemungkinan akan banyak informasi yang hilang. Untuk mengatasi permasalahan tersebut dapat digunakan pengambangan secara lokal adaptif. Pada pengambangan lokal, suatu citra dibagi-bagi menjadi blok-blok kecil dan kemudian dilakukan pengambangan lokal pada setiap blok dengan nilai $\mathrm{T}$ yang berbeda.

Setelah citra mengalami proses binerisasi, biasanya akan terdapat derau atau noise yang berpengaruh terhadap nilai vektor fitur citra. Oleh karena itu diperlukan cara untuk menghilangkan noise tersebut, yakni dengan menggunakan proses filtering. Pada proses filtering, terdapat banyak model yang bisa diterapkan seperti misalnya Mean Filtering, Median Filtering, Gaussian Filtering, Low-pass, High-pass, Kuwahara Filtering. Dari model tersebut masing-masing memiliki karakteristik yang berbeda, sehingga ketika memilih model filtering yang akan digunakan hendaknya disesuaikan dengan jenis noise yang terdapat dalam sebuah citra. Jika sebuah citra dianggap sudah bersih dari noise, maka proses selanjutnya adalah pendeteksian terhadap tepi objek, sehingga diharapkan bisa menghasilkan bentuk yang cukup jelas (Munir, 2004).

\subsection{Ekstraksi Fitur}

Dalam sebuah citra tentunya terdapat komponen-komponen penyusun citra. Di dalam komponen tersebut akan terdapat banyak informasi yang bisa diolah, sehingga bisa menghasilkan suatu informasi baru yang sangat berguna. Proses penggalian informasi yang terkandung dalam sebuah citra sering disebut dengan ekstraksi fitur. Biasanya dalam ekstraksi fitur ada tiga jenis fitur yang sering digali informasinya, yakni warna, tekstur, dan bentuk (Sujaya, 2011).

Jika sebuah citra sebelumnya telah mengalami segmentasi hingga dilakukan proses deteksi tepi, tentu saja informasi yang akan digali adalah bentuk dari objek. Salah satu metode yang bisa digunakan untuk mengekstrak fitur bentuk adalah momen invarian 
(Putra, 2010). Karakteristik dari metode ini adalah menghasilkan nilai-nilai yang invarian terhadap rotasi, translasi, pencerminan, dan skala, namun tidak invariant terhadap perubahan kontras (Muhtadan, 2009). Nilai-nilai yang diperoleh dari hasil perhitungan momen invarian biasanya dijadikan sebagai nilai vektor fitur. Berikut adalah persamaan 7 nilai momen invarian.

$$
\begin{aligned}
\emptyset_{1}= & \eta_{20}+\eta_{02} \\
\emptyset_{2}= & \left(\eta_{20}+\eta_{02}\right)^{2}+4 \eta_{11}^{2} \\
\emptyset_{5}= & \left(\eta_{30}-3 \eta_{12}\right)^{2}+\left(3 \eta_{21}-\eta_{03}\right)^{2} \\
\emptyset_{4}= & \left(\eta_{50}+\eta_{12}\right)^{2}+\left(\eta_{21}+\eta_{03}\right)^{2} \\
\emptyset_{5}= & \left(\eta_{50}-3 \eta_{112}\right)\left(\eta_{30}+\eta_{12}\right)\left\{\left(\eta_{30}+\eta_{12}\right)^{2}-3\left(\eta_{21}+\eta_{03}\right)^{2}\right\}+ \\
& \left(3 \eta_{21}-\eta_{03}\right)\left(\eta_{21}+\eta_{03}\right)\left\{3\left(\eta_{30}+\eta_{12}\right)^{2}-\left(\eta_{21}+\eta_{03}\right)^{2}\right\} \\
\emptyset_{6}= & \left(\eta_{20}-\eta_{02}\right)\left\{\left(\eta_{30}+\eta_{12}\right)^{2}-\left(\eta_{21}+\eta_{03}\right)^{2}\right\}+4 \eta_{11}\left(\eta_{30}+\eta_{12}\right)\left(\eta_{21}+\eta_{03}\right) \\
\emptyset_{7}= & \left(3 \eta_{21}-\eta_{130}\right)\left(\eta_{30}+\eta_{12}\right)\left\{\left(\eta_{30}+\eta_{12}\right)^{2}-3\left(\eta_{21}+\eta_{53}\right)^{2}\right\}+ \\
& \left(3 \eta_{21}-\eta_{03}\right)\left(\eta_{21}+\eta_{03}\right)\left\{3\left(\eta_{50}+\eta_{12}\right)^{2}-\left(\eta_{21}+\eta_{03}\right)^{2}\right\}
\end{aligned}
$$

\subsection{Pengelompokan Data}

Clustering merupakan pembagian data ke dalam suatu kelompok objek yang saling mirip. Setiap kelompok, disebut cluster, memuat objek-objek yang saling memiliki kemiripan satu sama lain dan memiliki perbedaan jika dibandingkan dengan objekobjek yang terdapat pada kelompok atau cluster lain. Dalam pembagian data ke dalam kelompok tidak perlu mencocokkan secara detail dengan masing-masing objek, melainkan cukup mencocokkan dengan karakteristik kelompok secara umum (Abbas, 2008). Analisis cluster bukan merupakan sebuah algoritma, melainkan suatu konsep yang didalamnya terdapat berbagai metode clustering.

Analisis cluster secara garis besar dibedakan menjadi dua jenis yakni analisis cluster dengan pola terbimbing (supervised) dan pola tidak terbimbing (unsupervised) (Putra, 2010). Pola terbimbing bisa dilakukan jika sebelumnya sudah terdapat kelas data 
ISSN 2089-8673

Jurnal Nasional Pendidikan Teknik Informatika (JANAPATI)

Volume 2, Nomor 1, Maret 2013

yang jelas (terbentuk sistem pengetahuan). Jika ada data sampel yang akan diklaster, maka tinggal mencocokkan dengan salah satu kelas yang sudah ada sebelumnya. Akan tetapi tidak selamanya bisa mendapatkan data untuk dijadikan sistem pengetahuan, sehingga diperlukan pola tidak terbimbing. Pada pola tidak terbimbing, jika data sudah diklaster dan datang lagi data lain, maka susunan data dalam klaster tersebut kecenderungan akan berubah. Pengelompokan terbimbing bisa dilakukan dengan cara mencari kemiripan data uji dengan data kelompok yang sudah ada, sedangkan pengelompokan non terbimbing adalah pengelompokan data yang semua jenis datanya belum diketahui.

Pada sistem ini menggunakan proses pengelompokan terbimbing, yang mana citra uji akan dikelompokkan ke dalam salah satu dari dua kelompok, yakni kelompok lakilaki dan kelompok perempuan. Untuk menyeragamkan nilai-nilai yang dimiliki oleh masing-masing anggota kelompok, sehingga bisa menjadi nilai tunggal yang bisa mewakili karakteristik anggota kelompok, maka dicari dengan menghitung nilai ratarata kelompok. Hanya saja hal yang perlu diperhatikan ketika mencari nilai rata-rata kelompok adalah adanya pencilan data (Soemartini, 2007).

Pencilan data adalah data yang memiliki nilai ekstrim, baik sangat tinggi maupun sangat rendah, sehingga guna meminimalisirnya diperlukan metode penghapusan pencilan data, salah satunya adalah IQR atau boxplot yang menggunakan nilai kuartil dan jangkauan kuartil. Kuartil 1, 2, dan 3 akan membagi sebuah urutan data menjadi empat bagian. Jangkauan (IQR, Interquartile Range) didefinisikan sebagai selisih kuartil 1 terhadap kuartil 3, atau IQR = Q3 Ï Q1. Data-data pencilan dapat ditentukan yaitu nilai yang kurang dari $1.5 * \mathrm{IQR}$ terhadap kuartil 1 dan nilai yang lebih dari 1.5*IQR terhadap kuartil 3 (Soemartini, 2007). Gambar 1 merupakan skema identifikasi pencilan menggunakan IQR atau boxplot. 
ISSN 2089-8673

Jurnal Nasional Pendidikan Teknik Informatika (JANAPATI)

Volume 2, Nomor 1, Maret 2013

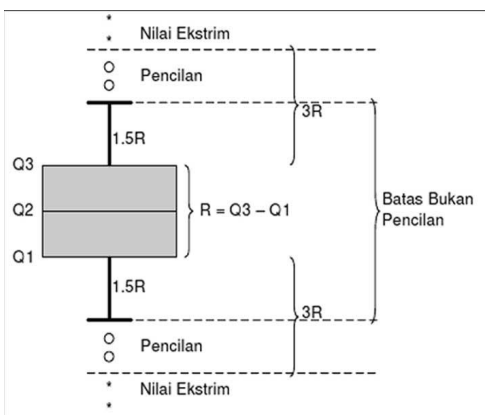

Gambar 1. Identifikasi Pencilan Menggunakan IQR atau boxplot

(Sumber: Soemartini, 2007)

Oleh karena hasil yang diperoleh dari ekstraksi fitur bentuk berupa nilai vektor, maka pada tahap pengelompokan data diperlukan cara untuk menghitung kemiripan yang dimiliki 2 buah vektor, yakni dengan menggunakan perhitungan normalisasi jarak euclid (Normalized Euclidean Distance). "Euclidean Distance adalah metrika yang paling sering digunakan untuk menghitung kesamaan 2 vektor. Euclidean Distance menghitung akar dari kuadrat perbedaan 2 vektor (root of square differences between 2 vectors)ò(Putra, 2010: 311).

Normalized Euclidean Distance adalah salah satu metode yang dipakai dalam pencocokan citra query dengan citra dalam database. Rentangan nilai kecocokan berkisar dari 0-2. Semakin kecil nilai jarak (distance) maka objek dikatakan semakin mirip atau cocok. Sebaliknya semakin besar nilai jarak (distance) maka dua objek dikatakan semakin berbeda (Putra, 2010). Sebenarnya metode ini dipakai untuk melihat kemiripan dua buah vektor dengan membandingkan titik-titik pembentuk vektor. Oleh karena itulah nilai deskripsi visual citra harus dibentuk ke dalam vektor yang dikenal sebagai feature vector.

\subsection{Analisis Perangkat Lunak}

Secara umum, perangkat lunak sistem identifikasi jenis kelamin janin ini diharapkan memiliki beberapa fungsi utama yaitu melakukan segmentasi citra, mengekstrak fitur bentuk objek, serta mengelompokkan data uji ke dalam salah satu kelompok berdasarkan kemiripan bentuk. 
ISSN 2089-8673

Jurnal Nasional Pendidikan Teknik Informatika (JANAPATI)

Volume 2, Nomor 1, Maret 2013

Tujuan dari pengembangan perangkat lunak ini adalah untuk dapat melakukan segmentasi citra, ekstraksi fitur bentuk, dan mengelompokkan data.

Masukan dari aplikasi ini adalah: 1) citra uji pada proses identifikasi merupakan file citra bertipe bitmap (*.bmp), dan citra yang diolah khusus citra USG kelamin janin dengan usia kehamilan minimal 5 bulan serta bukan janin kembar; 2) citra untuk knowledge system adalah citra USG kelamin janin (bertipe bitmap) yang sudah diidentifikasi oleh dokter kandungan yang sudah berpengalaman dari sebuah rumah sakit di kota Singaraja. Dari dokter tersebut diperoleh 54 citra USG dengan pembagian 33 citra janin laki-laki serta 21 citra janin perempuan, yang semua citra tersebut telah diyakini kebenarannya. Semua citra tersebut dijadikan sebagai pengetahuan sistem dalam proses identifikasi citra uji; dan 3) parameter kernel untuk proses filtering. Keluarannya adalah citra hasil thresholding, citra hasil filtering, citra hasil edge detection, hasil identifikasi jenis kelamin janin, bertambahnya pengetahuan sistem, serta about (informasi tentang aplikasi dan peneliti).

\subsection{Perancangan Perangkat Lunak}

Batasan perancangan perangkat lunak Sistem Identifikasi Jenis Kelamin Janin pada Citra USG yang akan dibuat ini adalah format citra input berekstensi bitmap (*.bmp). Perancangan arsitektur perangkat lunak menggambarkan bagian-bagian modul, struktur ketergantungan antar modul, dan hubungan antar modul dari perangkat lunak yang dibangun. Pada bagian ini terdapat Data Flow Diagram (DFD) Level 0 dan Structure Chart sebagai kendali fungsional yang digambarkan seperti Gambar 2 dan Gambar 3 untuk perangkat lunak Sistem Identifikasi Jenis Kelamin Janin pada Citra USG. 


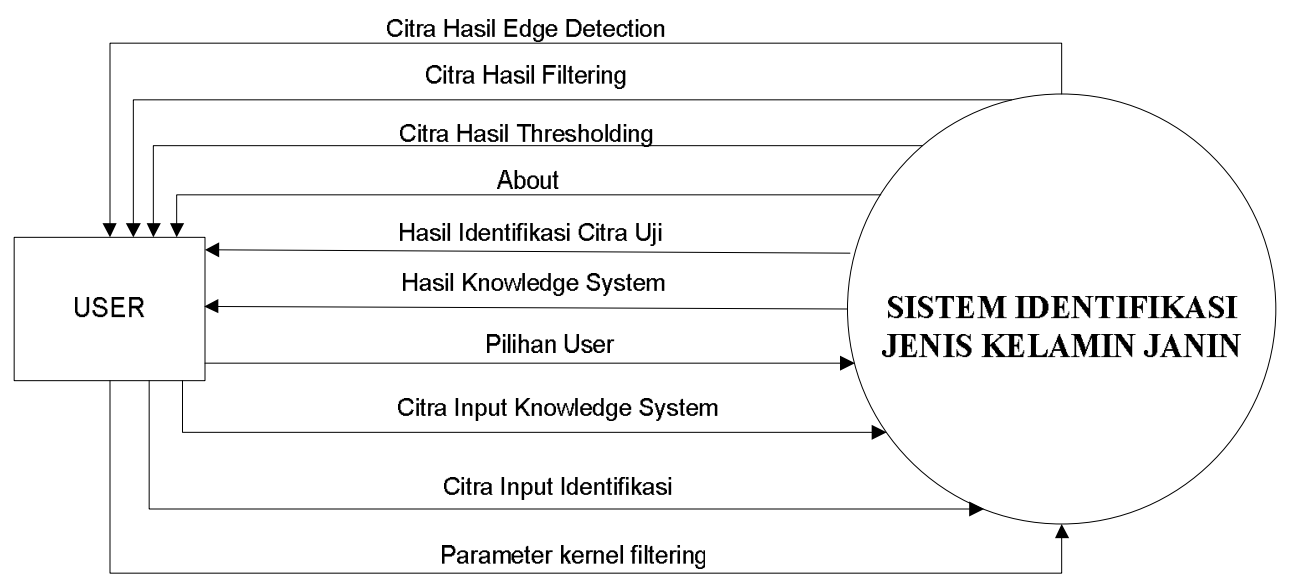

Gambar 2. DFD Level 0 Perangkat Lunak Sistem Identifikasi Jenis Kelamin Janin

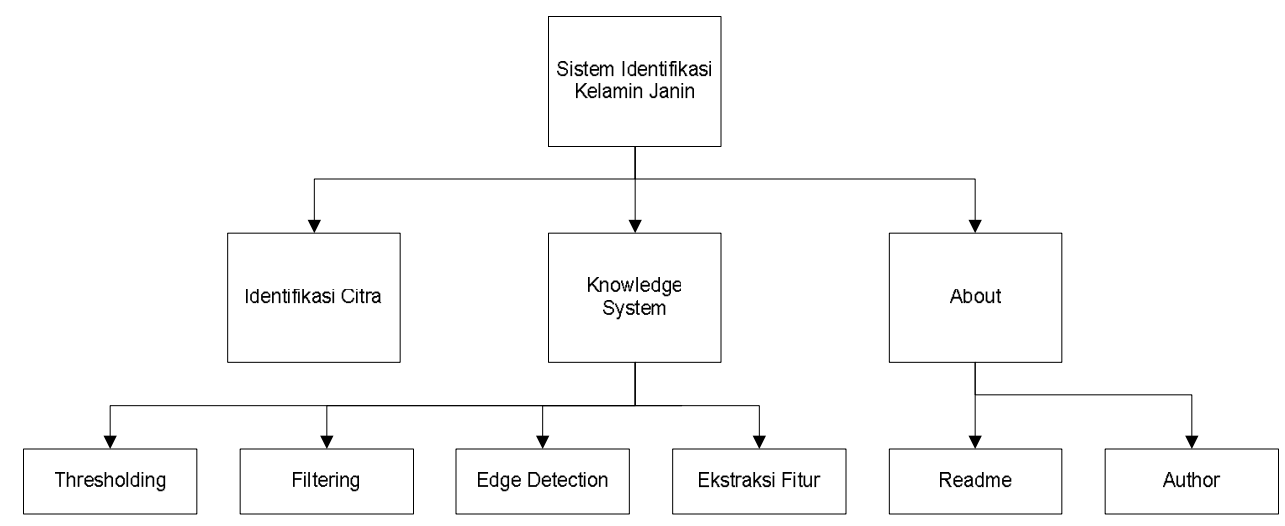

Gambar 3. Structure Chart Perangkat Lunak Sistem Identifikasi Jenis Kelamin Janin

\section{PEMBAHASAN}

\subsection{Implementasi Perangkat Lunak}

Data Flow Diagram (DFD) dan Rancangan Arsitektur Perangkat Lunak Sistem Identifikasi Jenis Kelamin Janin diimplementasikan dengan menggunakan bahasa pemrograman Delphi 2010. Gambar 4 merupakan pemetaan unit-unit yang digunakan pada Sistem Identifikasi Jenis Kelamin Janin. Pada Gambar 4 dapat dilihat ada 7 unit yang digunakan yakni: 1) UnitMain sebagai unit pemanggil unit lain; 2) UnitImageMatrices sebagai unit untuk mendefinisikan file bertipe bitmap, termasuk juga untuk mendefinisikan matriks; 3) UnitProcessing sebagai unit untuk menampung 
operasi matematis dalam pengolahan citra digital, sesuai dengan metode-metode yang digunakan; 4) UnitImageInput untuk menampung citra input baik citra uji maupun citra untuk proses penambahan pengetahuan sistem; 5) UnitIdentification merupakan unit untuk proses pengidentifikasian jenis kelamin janin pada citra USG; 6) UnitKnowledge adalah unit untuk menambah pengetahuan yang dimiliki sistem, dengan menyimpan nilai vektor fitur dari sebuah citra USG yang jenis kelamin janinnya sudah diketahui sebelumnya; dan 7) UnitAbout berisikan informasi mengenai sistem dan pembuat sistem.

Gambar 5 adalah tampilan form utama dari Sistem Identifikasi Jenis Kelamin Janin, yang mana terdapat 4 menu pada bagian menubar yakni File (hanya berisi sub menu Exit), Identification, Knowledge System, dan About. Menu Identification akan menampilkan form identification seperti yang ditunjukkan pada Gambar 7, yang berfungsi untuk mengidentifikasi citra USG yang akan diidentifikasi jenis kelaminnya. Selanjutnya menu Knowledge System akan menampilkan form knowledge system (Gambar 8) yang memungkinkan user untuk menambah basis pengetahuan sistem, dengan menyimpan nilai vektor fitur dari sebuah citra USG yang jenis kelaminnya sudah diketahui, sedangkan menu yang terakhir adalah About. Pada menu About terdapat 2 sub menu yakni Readme (Gambar 9a) dan Author (Gambar 9b). Readme berisi informasi singkat mengenai sistem, sedangkan Author berisi informasi mengenai pembuat sistem.

Ketika user mengaktifkan form identification ataupun form knowledge system, maka user akan diminta untuk membuka sebuah gambar. Gambar yang dibuka user akan ditampung dalam sebuah form yakni form Image Viewer (Gambar 6). Melalui form ini, user dapat melihat citra yang akan diproses, terutama pada proses knowledge system, yang mana akan diperlihatkan perubahan dari citra asal menjadi citra biner, selanjutnya citra biner yang mengalami proses filtering, dan yang terakhir adalah citra yang telah mengalami pendeteksian tepi. Berikut ini adalah pemetaan unit serta tampilan form dari Sistem Identifikasi Jenis Kelamin Janin. 


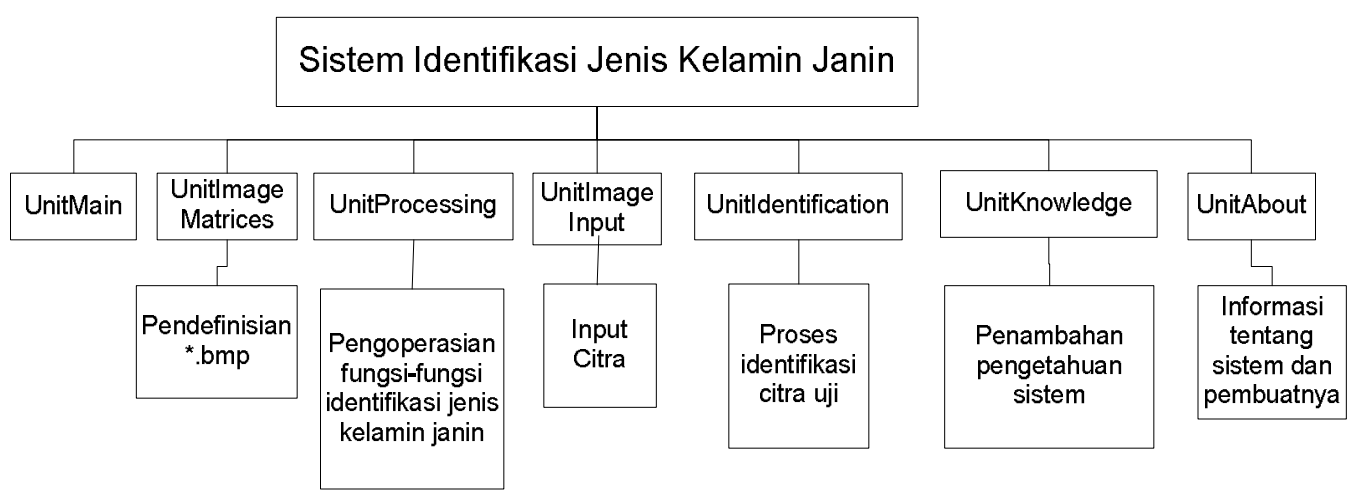

Gambar 4.Pemetaan Unit Sistem Identifikasi Jenis Kelamin Janin

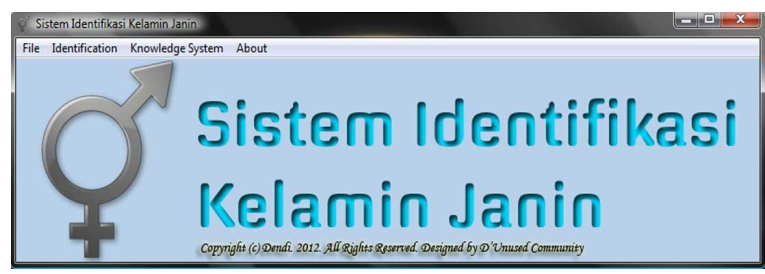

Gambar 5. Form Utama Sistem Identifikasi Jenis Kelamin Janin

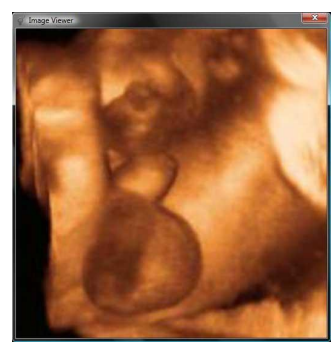

Gambar 6.Form Image Viewer Sistem Identifikasi Kelamin Janin

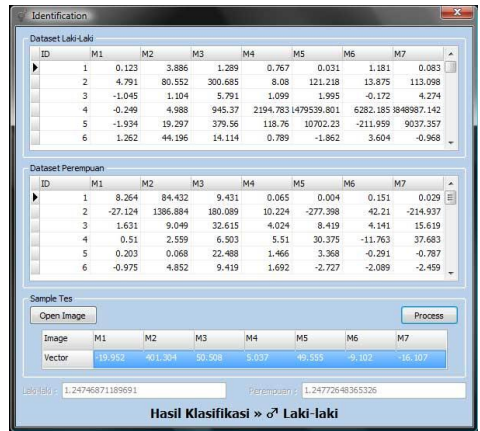

Gambar 7. Form Identification Sistem Identifikasi Kelamin Janin 
ISSN 2089-8673

Jurnal Nasional Pendidikan Teknik Informatika (JANAPATI)

Volume 2, Nomor 1, Maret 2013

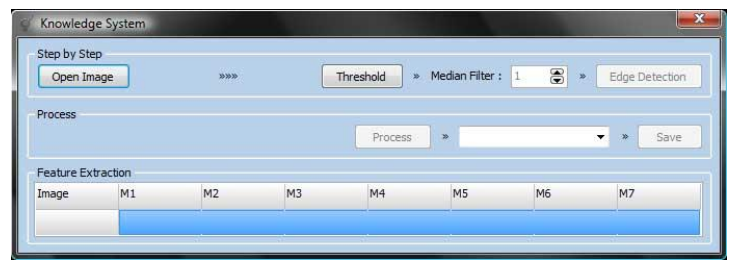

Gambar 8. Form Knowledge System Sistem Identifikasi Kelamin Janin

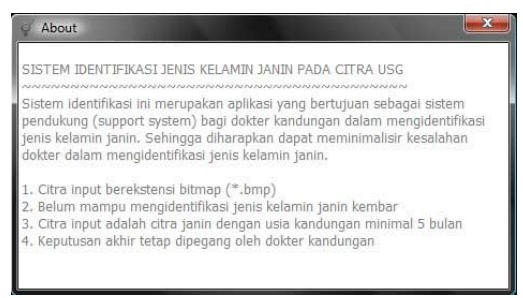

Gambar 9a. Form About ï Readme Sistem Identifikasi Kelamin Janin

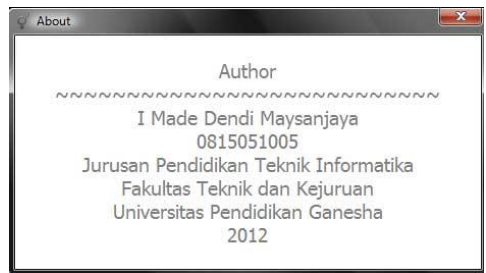

Gambar 9b. Form About Ï Author Sistem Identifikasi Kelamin Janin

\subsection{Pengujian Perangkat Lunak}

Pengujian perangkat lunak Sistem Identifikasi Kelamin Janin ini dilakukan penulis untuk uji performansi sistem.Sebelum pengujian dilakukan, penulis meminta bantuan kepada dokter kandungan untuk menyediakan citra USG janin dengan jenis kelamin laki-laki dan perempuan, dan diperoleh citra USG sejumlah 54 gambar dengan rincian 33 laki-laki dan 21 perempuan.

Terlebih dahulu semua sampel tersebut diolah sebagai basis pengetahuan. Setelah basis pengetahuan dimasukkan, tahap selanjutnya adalah menguji performa sistem dengan menggunakan kembali citra sampel sebagai citra uji. Hal ini untuk melihat seberapa akurat sistem dalam mengidentifikasi jenis kelamin janin. 
Pada pengujian awal, sistem hanya mampu memprediksi jenis kelamin laki-laki sebanyak 6 sampel dari 33 sampel laki-laki (18,18\%), dan untuk sampel perempuan mampu diprediksi sebanyak 14 sampel dari 21 sampel perempuan $(66,67 \%)$. Hal ini tidak sesuai dengan teori yang menyatakan bahwa jenis kelamin laki-laki lebih mudah diidentifikasi, dan justru jenis kelamin perempuan yang agak susah diidentifikasi. Setelah dianalisa lebih lanjut, ternyata pada saat melakukan pengelompokan data tidak memperhatikan adanya pencilan data, yaitu data-data yang termasuk dalam kategori data dengan nilai ekstrim tinggi dan ekstrim rendah. Pencilan data ini akan berpengaruh besar terhadap rata-rata yang dimiliki oleh sekelompok data. Oleh karena itu sebelum mencari rata-rata kelompok, terlebih dahulu dilakukan perhitungan untuk menghilangkan pencilan data, setelah itu barulah dicari rata-rata tiap kelompok.

Dari 33 sampel laki-laki, yang berhasil teridentifikasi sesuai prediksi dokter sebanyak 24 sampel $(72,73 \%)$ dan yang tidak sesuai sebanyak 9 sampel $(27,27 \%)$. Sedangkan dari 21 sampel perempuan, yang berhasil teridentifikasi sebanyak 12 sampel $(57,14 \%)$ dan yang tidak sesuai sebanyak 9 sampel (42,56\%). Hasil ini cukup sesuai dengan pernyataan pada teori yang menyatakan bahwa jenis kelamin laki-laki lebih mudah diidentifikasi daripada jenis kelamin perempuan. Hal ini karena dari segi bentuk, jenis kelamin laki-laki lebih mudah dilihat secara kasat mata daripada jenis kelamin perempuan, sehingga untuk keseluruhan sampel, berhasil teridentifikasi dengan benar sebanyak 36 dari 54 sampel atau sebesar 66,67\%, sedangkan yang tidak sesuai sebanyak 18 dari 54 sampel atau 33,33\%. Gambar 10a, b, c, dan d berturut-turut merupakan gambar yang diambil dari sampel uji, berdasarkan dari hasil pengujian sistem. Gambar 10a merupakan gambar janin laki-laki yang memiliki jarak kemiripan paling dekat dengan kelompok laki-laki (0.27125066877579), sedangkan Gambar 10b kebalikan dari Gambar 10a, yakni gambar janin laki-laki yang memiliki jarak kemiripan paling jauh dengan kelompok laki-laki (1.53601346871359). Sementara Gambar 10c adalah gambar janin perempuan yang paling mirip dengan kelompok perempuan (0.0897165585070659), dan Gambar 10d adalah gambar janin perempuan yang memiliki jarak kemiripan paling jauh dengan kelompok perempuan (1.54266686720371). 
ISSN 2089-8673

Jurnal Nasional Pendidikan Teknik Informatika (JANAPATI)

Volume 2, Nomor 1, Maret 2013

Sebelum sebuah citra bisa diidentifikasi, terlebih dahulu citra harus diolah dengan tahapan sebagai berikut.

1. Citra input diubah menjadi citra biner dengan menggunakan model Local Thresholding. Keuntungan menggunakan Local Thresholding dibandingkan dengan Global Thresholding yakni kualitas binerisasi yang dihasilkan lebih presisi.

2. Setelah citra menjadi citra biner, langkah selanjutnya adalah menghilangkan noise yang dihasilkan dari proses binerisasi. Adapun model filtering yang digunakan adalah Median Filter.

3. Jika citra telah bersih dari noise, maka citra bisa dikenakan proses deteksi tepi, sehingga akan dihasilkan citra yang di dalamnya terdapat gambar seperti pulau. Operator deteksi yang digunakan yakni operator Robert, yang menghasilkan garis tepi cukup tipis. Jika garis tepi cukup tebal akan berpengaruh terhadap nilai pixel citra.

4. Setelah citra mengalami proses pendeteksian tepi, berarti tahap segmentasi sudah dilewati, sehingga tahap selanjutnya adalah proses pengekstraksian fitur bentuk yang dimiliki oleh citra. Dari proses ini, diperoleh 7 buah nilai sesuai dengan perhitungan menggunakan momen invarian.

5. Dari nilai momen yang diperoleh pada tahap ekstraksi fitur, selanjutnya nilai tersebut digunakan untuk menghitung jarak kemiripan citra uji dengan nilai momen yang dimiliki oleh masing-masing kelompok, dengan menggunakan normalisasi jarak euclid. Hasil yang diperoleh dari perhitungan tersebut, selanjutnya ditentukan citra uji akan dimasukkan ke kelompok mana, tergantung kemana jarak yang lebih dekat.

6. Dengan diperolehnya informasi mengenai kelompok yang diperoleh citra uji, maka proses identifikasi secara keseluruhan sudah selesai. Sedangkan untuk tahap penambahan basis pengetahuan, langkah yang ditempuh sama hingga langkah 4, sedangkan tahap selanjutnya adalah menyimpan nilai vektor fitur ke dalam database, dan proses penambahan basis pengetahuan sistem pun selesai. 
Berikut adalah visualisasi proses pengolahan citra USG dari citra asli hingga mendapatkan nilai ekstraksi fitur.

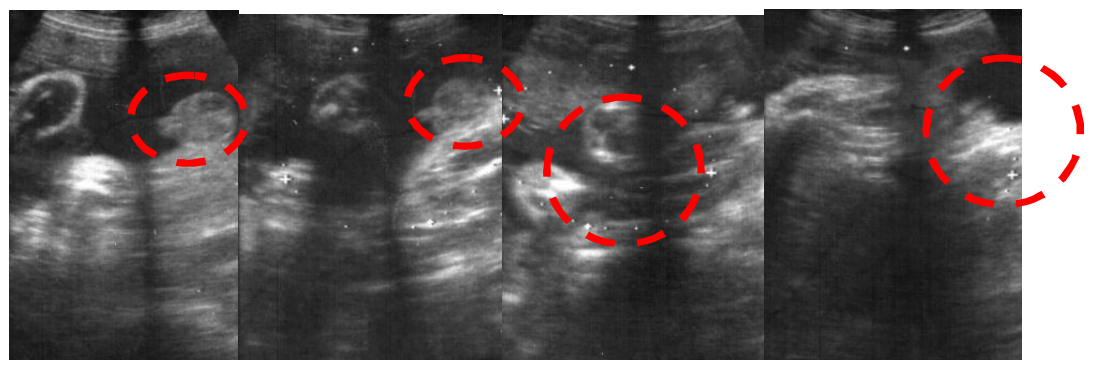

Dari kiri ke kanan: Gambar 10a, 10b, 10c, dan 10d. Lingkaran putus-putus merah adalah area kelamin janin

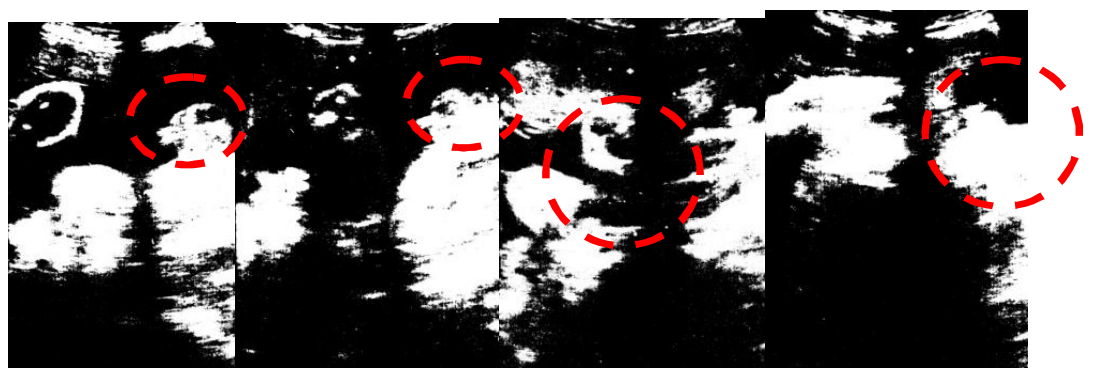

Dari kiri ke kanan: Hasil Thresholding Gambar 10a, 10b, 10c, dan 10d

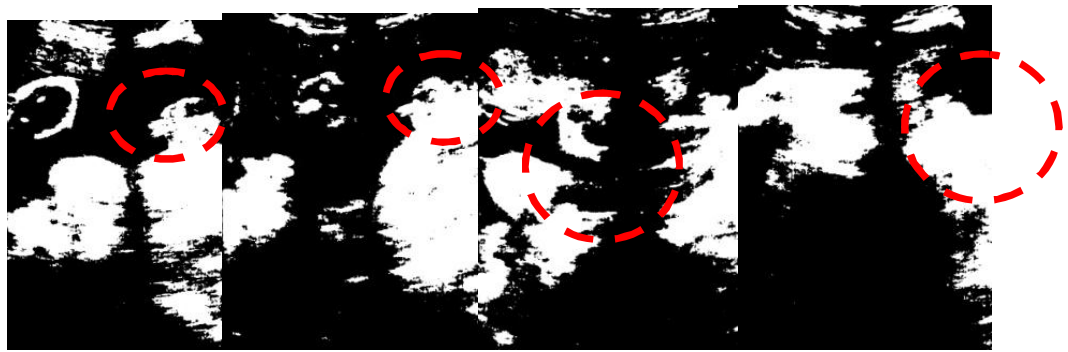

Dari kiri ke kanan: Hasil Filtering Citra Thresholding Gambar 10a, 10b, 10c, dan $10 \mathrm{~d}$ 


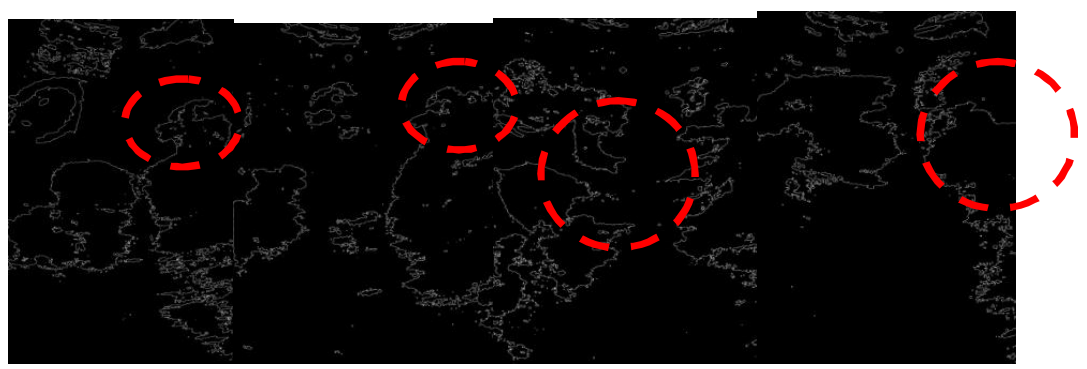

Dari kiri ke kanan: Hasil Edge Detection Citra Filtering Gambar 10a, 10b, 10c, dan $10 \mathrm{~d}$

Setelah citra mengalami proses segmentasi citra, langkah selanjutnya adalah mengekstrak fitur yang terdapat dalam citra tersebut, dengan menggunakan metode momen invarian yang hasilnya dapat dilihat pada Tabel 1. Selanjutnya masing-masing nilai tersebut akan dicocokkan satu-persatu dengan nilai vektor fitur yang dimiliki oleh kelompok laki-laki dan nilai-nilai yang dimiliki oleh kelompok perempuan, dengan membandingkan kedekatan jarak antara keduanya.

Tabel 1. Hasil Ekstraksi Fitur Citra Uji

\begin{tabular}{|c|c|c|c|c|c|c|c|}
\hline Citra & M1 & M2 & M3 & M4 & M5 & M6 & M7 \\
\hline 10a & 1.82 & 3.362 & 29.253 & 1.156 & -2.756 & 0.067 & -3.263 \\
\hline 10b & -1.934 & 19.297 & 379.56 & 118.76 & 10702.23 & -211.959 & 9037.357 \\
\hline 10c & 0.203 & 0.068 & 22.488 & 1.466 & -2.727 & -0.291 & -0.787 \\
\hline 10d & 1.539 & 2.382 & 129.818 & 308.714 & 8.419 & -76.063 & 8484.332 \\
\hline
\end{tabular}

Keterangan:

M1 = Center of Gravity; M2 = Relative Smoothness; M3 = Histogram Skewness;

M4 = Relative Flatness; M5, M6, M7 = Tidak ditemukan literatur yang menjelaskan makna nilai momen ini.

Dalam pengujian ini tidak dapat ditentukan apakah hasil yang diperoleh bisa dikatakan valid atau tidak. Pengujian dilakukan untuk melihat apakah sistem yang dikembangkan sudah mampu untuk mengidentifikasi jenis kelamin janin pada citra USG. Hasil tersebut tidak dikonfirmasi kepada dokter kandungan yang dijadikan 
ISSN 2089-8673

Jurnal Nasional Pendidikan Teknik Informatika (JANAPATI)

Volume 2, Nomor 1, Maret 2013

sebagai nara sumber, mengingat keterbatasan waktu penelitian. Dalam hal ini untuk 18 sampel yang tidak sesuai dari 54 citra uji, tidak dapat divonis apakah sistem yang memang salah atau justru judgement dokter ketika memberikan citra sampel yang salah. Dari sini masih nampak adanya beberapa kelemahan yang dimiliki oleh sistem, yang secara mendasar diakibatkan masih minimnya citra USG yang dijadikan sebagai basis pengetahuan, mengingat untuk mendapatkan sebuah citra USG memerlukan proses serta waktu yang relatif lama, sehingga jika dibandingkan antara hasil yang dicapai dengan kelemahan yang dimiliki, dapat dikatakan bahwa sistem ini cukup layak untuk dikembangkan ataupun dijadikan acuan dalam upaya mengembangkan sistem pengidentifikasian terhadap citra USG yang lebih kompleks, serta tidak hanya terbatas pada identifikasi jenis kelamin janin.

\section{PENUTUP}

\subsection{Simpulan}

Berdasarkan hasil analisis, implementasi dan pengujian pada penelitian ini, maka dapat diambil simpulan bahwa Sistem Identifikasi Kelamin Janin diimplementasikan menggunakan bahasa pemrograman Embarcadero Delphi 2010 Architecture dengan menggunakan 3 jenis metode pada pengolahan citra digital, yaitu segmentasi citra, ekstraksi fitur, dan pengelompokan data. Dari data hasil uji coba pengidentifikasian jenis kelamin janin, didapat bahwa sebagian besar jenis kelamin citra USG janin berhasil diidentifikasi dengan baik. Dalam hal ini Sistem Identifikasi Kelamin Janin dapat dipergunakan sebagai support system bagi dokter kandungan pada saat mengidentifikasi jenis kelamin janin, sehingga dengan ditunjang oleh pengalaman dokter tersebut maka akurasi hasil identifikasi jenis kelamin janin dapat ditingkatkan.

\subsection{Saran}

Berdasarkan hasil pengamatan yang diperoleh dari penelitian ini, serta mengingat masih cukup banyak batasan yang dimiliki Sistem Identifikasi Jenis Kelamin Janin, disarankan bagi pembaca yang ingin mengembangkan sistem ini agar berupaya menambah pengetahuan yang dimiliki oleh sistem, serta memperbaharui metodemetode pada pengolahan citra yang dipergunakan, terutama metode-metode yang 
ISSN 2089-8673

Jurnal Nasional Pendidikan Teknik Informatika (JANAPATI)

Volume 2, Nomor 1, Maret 2013

digunakan pada tahap ekstraksi fitur dan tahap pengelompokan data. Dengan demikian dapat diharapkan akurasi sistem identifikasi kelamin janin ini bisa semakin ditingkatkan, serta bisa dikembangkan menjadi sistem identifikasi terhadap seluruh bagian janin.

\section{DAFTAR PUSTAKA}

Abbas, Osama Abu. 2008. ñComparisons Between Data Clustering Algorithmsò. The International Arab Journal of Information Technology, Vol. 5, No. 3.

Muhtadan. 2009. ñEkstraksi Ciri Cacat Pengelasan Pada Citra Digital Film Radiografi Menggunakan Geometric Invariant Moment dan Statistical Textureò. JFN, Vol. 3, No. 2.

Munir, Rinaldi.2004. Pengolahan Citra Digital dengan Pendekatan Algoritmik. Bandung: Penerbit Infomatika Bandung.

Putra, Darma. 2010. Pengolahan Citra Digital Ï Ed. 1.Yogyakarta: Penerbit ANDI.

Soemartini. 2007. Pencilan (Outlier). Jatinangor: Universitas Padjadjaran.

Sujaya, Gede. 2011. Pengembangan Sistem Temu Kembali Citra Berdasarkan Deskripsi Warna, Tekstur, dan Bentuk Objek. Skripsi (Tidak diterbitkan). Jurusan Pendidikan Teknik Informatika, Undiksha Singaraja. 